\title{
tan \\ Effect of Vitamin D Deficiency on COVID-19 Status: A Systematic Review
}

\author{
Pranta Das ${ }^{1}\left(\mathbb{D}\right.$, Nandeeta Samad ${ }^{2}$, Bright Opoku Ahinkorah ${ }^{3}\left(\mathbb{D}\right.$, John Elvis Hagan, Jr. ${ }^{4,5}, * \mathbb{}$, Prince Peprah ${ }^{6}$, \\ Aliu Mohammed ${ }^{5}$ and Abdul-Aziz Seidu ${ }^{7,8}$
}

check for

updates

Citation: Das, P.; Samad, N.;

Ahinkorah, B.O.; Hagan, J.E., Jr.;

Peprah, P.; Mohammed, A.; Seidu,

A.-A. Effect of Vitamin D Deficiency on COVID-19 Status: A Systematic

Review. COVID 2021, 1, 97-104.

https://doi.org/10.3390/

covid1010008

Academic Editor: Stefano Aquaro

Received: 24 February 2021

Accepted: 2 July 2021

Published: 7 July 2021

Publisher's Note: MDPI stays neutral with regard to jurisdictional claims in published maps and institutional affiliations.

Copyright: (c) 2021 by the authors. Licensee MDPI, Basel, Switzerland. This article is an open access article distributed under the terms and conditions of the Creative Commons Attribution (CC BY) license (https:/ / creativecommons.org/licenses/by/ $4.0 /)$.
1 Department of Statistics, University of Dhaka, Dhaka 1000, Bangladesh; pranta.du.stat@gmail.com

2 Department of Public Health, North South University, Dhaka 1000, Bangladesh; nandeeta6@gmail.com

3 School of Public Health, Faculty of Health, University of Technology Sydney, Sydney, NSW 2007, Australia; brightahinkorah@gmail.com

4 Neurocognition and Action-Biomechanics-Research Group, Faculty of Psychology and Sport Sciences, Bielefeld University, 33501 Bielefeld, Germany

5 Department of Health, Physical Education and Recreation, University of Cape Coast, Cape Coast PMB TF 0494, Ghana; aliu.mohammed@stu.ucc.edu.gh

6 Social Policy Research Centre, Centre for Primary Health Care and Equity, University of New South Wales, Sydney, NSW 2052, Australia; p.peprah@unsw.edu.au

7 Department of Population and Health, University of Cape Coast, Cape Coast PMB TF 0494, Ghana; abdul-aziz.seidu@stu.ucc.edu.gh

8 College of Public Health, Medical and Veterinary Sciences, James Cook University, Townsville, QLD 4811, Australia

* Correspondence: elvis.hagan@ucc.edu.gh

\begin{abstract}
One major micronutrient studied for its possible protective effect against the COVID-19 disease is vitamin D. This systematic review sought to identify and synthesize available evidence to aid the understanding of the possible effect of vitamin D deficiency on COVID-19 status and health outcomes in COVID-19 patients. Three databases (PubMed, ScienceDirect, and Google Scholar) were systematically used to obtain English language journal articles published between 1 December 2019 and 3 November 2020. The search consisted of the terms ("Vitamin D," OR "25-Hydroxyvitamin D," OR “Low vitamin D.") AND (“COVID-19" OR “2019-nCoV” OR “Coronavirus" OR "SARS-CoV-2”) AND ("disease severity" OR "IMV" OR "ICU admission" OR "mortality" OR "hospitalization" OR "infection"). We followed the recommended PRISMA guidelines in executing this study. After going through the screening of the articles, eleven articles were included in the review. All the included studies reported a positive association between vitamin D sufficiency and improved COVID-19 disease outcomes. On the other hand, vitamin D deficiency was associated with poor COVID-19 disease outcomes. Specifically, two studies found that vitamin D-deficient patients were more likely to die from COVID-19 compared to vitamin D-sufficient patients. Three studies showed that vitamin D-deficient people were more likely to develop severe COVID-19 disease compared to vitamin D-sufficient people. Furthermore, six studies found that vitamin D-deficient people were more likely to be COVID-19 infected compared to vitamin D-sufficient people. Findings from these studies suggest that vitamin D may serve as a mitigating effect for COVID-19 infection, severity, and mortality. The current evidence supports the recommendations for people to eat foods rich in vitamin D such as fish, red meat, liver, and egg yolks. The evidence also supports the provision of vitamin D supplements to individuals with COVID-19 disease and those at risk of COVID-19 infection in order to boost their immunity and improve health outcomes.
\end{abstract}

Keywords: COVID-19; 25-hydroxyvitamin D; SARS-CoV-2 virus; vitamin D

\section{Introduction}

As of 10 November 2020, approximately 50 million confirmed cases and 1.2 million COVID-19-related deaths had been reported globally [1]. There is a seemingly sharp rise in 
the number of confirmed COVID-19 cases in many countries, in what has been described as the "second wave" of the global pandemic [2]. For instance, between September and October 2020, a number of European countries including Belgium, Germany, France, Spain, Czech Republic, and Ireland had reported exponential increases in the daily number of confirmed COVID-19 cases [2]. This resurgence of the disease has been attributed to the relaxation of preventive measures such as lockdowns, physical distancing, wearing of face coverings, and the general disregard to precautionary behaviors among the populace [3,4]. Therefore, in the absence of effective pharmacologic therapy and vaccines, it is important to investigate the role of immune boosters such as micronutrients (vitamins and minerals) in mitigating or preventing the adverse effect of the COVID-19 disease [5,6].

One major micronutrient studied for its possible protective or mitigating effect against the COVID-19 disease is vitamin D [7-9], which is mostly produced in the skin after exposure to ultraviolent radiation from the sun or consumed from dietary sources [10]. Because COVID-19 is associated with immune hyperactivation [11], the protective effect of vitamin $\mathrm{D}$ has been attributed to its ability to regulate immune responses to the COVID-19 virus [12], thereby reducing the risk or severity of acute respiratory distress syndrome, a cardinal sign of severe COVID-19 and mortality related to COVID-19 [11,13]. Relatedly, vitamin D deficiency has been associated with increasing risk for immune-mediated and inflammatory disorders including diseases of the respiratory and digestive systems [10]. Many observational studies have shown a significant association between low serum levels of vitamin $\mathrm{D}$ and increased risk for acute respiratory tract infections [14,15]. Additionally, a randomized controlled trial has shown that vitamin D supplementation for patients at high risk of respiratory tract infection reduces symptoms and need for antibiotic therapy [16].

Aside from its importance in immune modulation [10,16] during early and late phases of COVID-19 viral infection [17], the effect of vitamin D on health outcomes among COVID19 patients largely remains inconclusive $[17,18]$. One major postulate on the possible association of vitamin D deficiency and COVID-19 disease is the high morbidity and mortality recorded among aged populations, who are more likely to have lower serum levels of vitamin D [5,7]. For instance, Ilie et al. [19] reported that the aged population in countries with higher levels of COVID-19 mortality such as Italy and Spain had significantly lower mean serum levels of vitamin D. Additionally, both severe COVID-19 and vitamin D deficiency have been associated with common risk factors such as old age, obesity, and being of Asian or black ethnic descent [17]. Aside, the sharp decline in COVID-19 cases during the summer in most European countries (June, July, and August, 2020) and the sudden surge in cases during the autumn (September, October, and November, 2020) had been linked to the seasonal fluctuations of vitamin D plasma levels [20]. High plasma levels of vitamin D occur when ultraviolet (UV) radiation from the sun increases (e.g., during summer) and low plasma levels occur when the sun's UV decreases (e.g., during autumn) [21]. Thus, considering the numerous findings from observational studies on a possible association between vitamin D deficiency and the incidence or severity of COVID-19 disease, we conducted a systematic review with the aim of identifying and synthesizing available evidence to aid the understanding of the possible effect of vitamin D deficiency on COVID-19 status and health outcomes in COVID-19 patients.

\section{Materials and Methods}

\subsection{Search Strategy}

Three databases (PubMed, ScienceDirect, and Google Scholar) were systematically searched to obtain English language journal articles published between 1st December, 2019 to 3 November, 2020. The search consisted of the terms ("vitamin D," OR "25Hydroxyvitamin D," OR “Low vitamin D") AND ("COVID-19" OR “2019-nCoV" OR "Coronavirus" OR "SARS-CoV-2") AND ("disease severity" OR "IMV" OR "ICU admission" OR "mortality" OR "hospitalization" OR "infection"). More details regarding the 
search strategy are presented in Tables S1-S3 in the supplementary file. The systematic search was conducted by two authors (PD and NS) independently.

\subsection{Eligibility Criteria}

The studies which dealt with vitamin D deficiency and assessed the outcome of COVID19 infection, severity, and death among the real-time reverse transcriptase-polymerase chain reaction (RT-PCR) or according to the country specific criteria or laboratory-confirmed COVID-19 patients were included. Only peer-reviewed journal articles written in English language were included due to reliability and understandability of the data. Thus, unpublished studies, preprints, and articles written in languages other than English were excluded. Only studies which were cross-sectional or cohort or case-control study in nature were included. Hence, randomized controlled trails (RCTs), short communication, letter to the editor, and review articles were excluded. The conclusion obtained from an observational study and RCT is different, which is why to make the conclusions homogeneous, RCTs were excluded from the review. The screening of the studies was performed by two authors (PD and NS) independently. Any discrepancies between the authors were resolved through discussions. The discussions focused on providing justification for inclusion or exclusion of studies based on evidence from available literature and the aims of the current study.

\subsection{Data Extraction and Study Quality Assessment}

After selecting pertinent articles by using the inclusion and exclusion criteria, two authors (PD and NS) independently assessed the quality of the articles and extracted the data. The Newcastle-Ottawa technique was used to measure the quality of the included cross-sectional, cohort, and case-control studies, respectively. Studies with a quality score of at least 5 that used the appropriate criteria for their study design were selected for data extraction. The name of the first author, study design, country name, sample size, mean/median, age/age interval of the included participants, how vitamin D deficiency was defined, outcome assessed, and main findings were extracted from the included studies.

\section{Results}

\subsection{Search Results}

Through searching the databases (PubMed, Goggle Scholar, and ScienceDirect), 135, 2630, and 9 articles were identified, respectively (Figure 1). The titles and abstracts of 2774 articles were initially screened. Through the screening, 17 articles were selected for full-text screening. After the full-text screening of 17 articles, 3 articles were excluded due to mismatch of the study design. Then, from the rest of the eligible articles, 3 articles were excluded due to the lack of information and duplication. Finally, for qualitative synthesis, 11 articles were included.

\subsection{Study Characteristics and Main Findings}

Six cohort studies, one case-control study, and four cross-sectional studies comprised the 11 studies included for qualitative synthesis. Two studies were from USA, UK, and Iran each, and the rest of the studies were from different countries. Six studies investigated the outcome of COVID-19 infection, three studies investigated severity, and two studies investigated death. Different studies defined vitamin D deficiency differently. All the included studies were of moderate to high quality (Tables S4-S6 in the supplementary file). More comprehensive characteristics of the studies are presented in Table 1. 


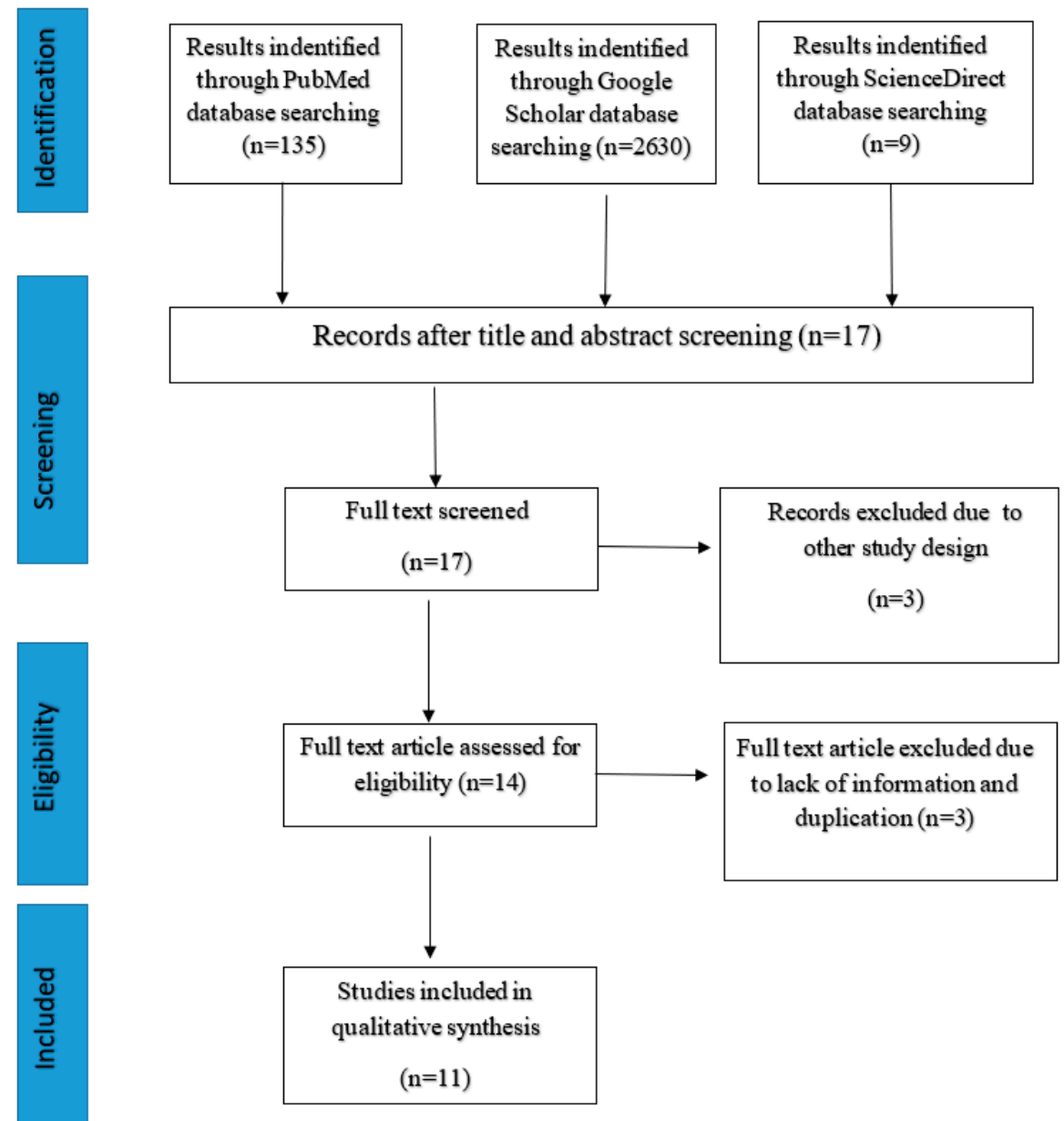

Figure 1. PRISMA Flowchart for Search Strategy and the Articles Selection Process.

Table 1. Study Characteristics.

\begin{tabular}{|c|c|c|c|c|c|c|}
\hline Author & Study Design & Country & Sample Size & $\begin{array}{c}\text { Mean/Median } \\
\text { Age/Age Interval } \\
\text { (Years) }\end{array}$ & $\begin{array}{l}\text { Vitamin D } \\
\text { Categories }\end{array}$ & $\begin{array}{l}\text { Outcome } \\
\text { Assessed }\end{array}$ \\
\hline Radujkovic et al., 2020 & Prospective cohort & Germany & 185 & 60 & $\begin{array}{l}\text { Deficiency: } \\
<12 \text { ng/mL }\end{array}$ & Death \\
\hline Meltzer et al., 2020 & $\begin{array}{l}\text { Retrospective } \\
\text { cohort }\end{array}$ & USA & 489 & 49.2 & $\begin{array}{l}\text { Deficiency: } \\
<20 \mathrm{ng} / \mathrm{mL}\end{array}$ & Infection \\
\hline Kaufman et al., 2020 & Cross-sectional & USA & 188,028 & 54 & $\begin{array}{l}\text { Deficiency: } \\
<20 \mathrm{ng} / \mathrm{mL}\end{array}$ & Infection \\
\hline Macaya F et al., 2020 & $\begin{array}{l}\text { Retrospective } \\
\text { cohort }\end{array}$ & Spain & 80 & $50-84$ & $\begin{array}{l}\text { Deficiency: } \\
<20 \mathrm{ng} / \mathrm{mL}\end{array}$ & Severity \\
\hline Hastie et al., 2020 & Cross-sectional & UK & 1474 & $38-58$ & $\begin{array}{l}\text { Deficiency: } \\
<10 \mathrm{ng} / \mathrm{mL}\end{array}$ & Infection \\
\hline Abrishami et al., 2020 & $\begin{array}{l}\text { Retrospective } \\
\text { cohort }\end{array}$ & Iran & 73 & 55.18 & $\begin{array}{l}\text { Deficiency: } \\
<25 \mathrm{ng} / \mathrm{mL}\end{array}$ & Death \\
\hline Merzon et al., 2020 & Cross-sectional & Israel & 7807 & 46.17 & $\begin{array}{l}\text { Deficiency: } \\
<30 \mathrm{ng} / \mathrm{ml}\end{array}$ & Infection \\
\hline Baktash et al., 2020 & $\begin{array}{l}\text { Prospective cohort } \\
\text { study }\end{array}$ & UK & 105 & 81.29 & $\begin{array}{l}\text { Deficiency: } \\
\leq 12 \mathrm{ng} / \mathrm{mL}\end{array}$ & Infection \\
\hline Maghbooli et al., 2020 & Cross-sectional & Iran & 235 & 58.72 & $\begin{array}{l}\text { Deficiency: } \\
<30 \mathrm{ng} / \mathrm{mL}\end{array}$ & Severity \\
\hline Ye et al., 2020 & Case-control study & China & 142 & 43 & $\begin{array}{l}\text { Deficiency: } \\
<20 \mathrm{ng} / \mathrm{mL}\end{array}$ & Severity \\
\hline D'avolio et al., 2020 & $\begin{array}{l}\text { Retrospective } \\
\text { cohort }\end{array}$ & Switzerland & 107 & 73 & Not categorized & Infection \\
\hline
\end{tabular}




\subsection{Findings from All the Studies}

Findings from the included studies are presented in Table 2.

Table 2. Findings from Studies.

\begin{tabular}{|c|c|}
\hline Author & Main Findings \\
\hline Radujkovic et al., 2020 & Vitamin D deficiency was associated with higher risk of death $(\mathrm{HR}=14.73, p<0.05)$ \\
\hline Meltzer et al., 2020 & $\begin{array}{l}\text { Patients with likely deficient vitamin D status at the time of COVID-19 testing had an increased relative } \\
\text { risk of testing positive for COVID-19 (relative risk, } 1.77 ; 95 \% \text { CI, } 1.12-2.81 ; p<0.05 \text { ) compared with } \\
\text { patients with likely sufficient status at the time of COVID-19 testing, for an estimated mean rate in the } \\
\text { deficient group of } 21.6 \% \text { vs. } 12.2 \% \text { in the sufficient group }\end{array}$ \\
\hline Kaufman et al., 2020 & $\begin{array}{l}\text { The SARS-CoV-2 positivity rate was lower in the } 27,870 \text { patients with "adequate" } 25(\mathrm{OH}) \mathrm{D} \text { values } \\
(30-34 \mathrm{ng} / \mathrm{mL})(8.1 \%) \text {, than in the } 39,190 \text { patients with "deficiency" }(<20 \mathrm{ng} / \mathrm{mL})(12.5 \%) \text { (difference } \\
35 \% ; p<0.05) \text {. Similarly, the SARS-CoV-2 positivity rate was lower in the } 12,321 \text { patients with } 25(\mathrm{OH}) \mathrm{D} \\
\text { values }>55 \mathrm{ng} / \mathrm{mL}(5.9 \%) \text { than in patients with adequate values (difference } 27 \% ; p<0.05)\end{array}$ \\
\hline Macaya F et al., 2020 & $\begin{array}{l}\text { After adjusting for age, gender, obesity, and severe CKD, the odds ratio for vitamin D-deficient people } \\
\text { to have severe COVID-19 was } 3.2 \text { ( } 95 \% \text { CI: } 0.9-11.4), p<0.05 \text { compared to vitamin D-sufficient people }\end{array}$ \\
\hline Hastie et al., 2020 & $\begin{array}{l}\text { Vitamin D deficiency has significant effect on COVID-19 infection in absence of confounders which is } \\
\text { deficient people are more likely to be positive [OR }=1.37, p<0.05] \text {. }\end{array}$ \\
\hline Abrishami et al., 2020 & $\begin{array}{l}\text { - The probability of death in patients with vitamin D deficiency [defined as } 25(\mathrm{OH}) \mathrm{D} \text { concentration } \\
<25 \mathrm{ng} / \mathrm{mL} \text { ] was } 34.6 \% \text { compared with } 6.4 \% \text { in patients with sufficient vitamin D levels }(p<0.05) \text {. } \\
\text { Odds of death was significantly higher in vitamin D-deficient patients }(<25 \mathrm{ng} / \mathrm{mL})[\mathrm{aOR}=6.84, p \\
<0.05 \text { ] in comparison with discharged patients. }\end{array}$ \\
\hline
\end{tabular}

- The mean plasma vitamin D level was significantly lower among those who tested positive than negative for COVID-19 [19.00 ng/mL vs. 20.55].

Merzon et al., 2020 - After controlling for the confounders, patients with low $25(\mathrm{OH}) \mathrm{D}(<30 \mathrm{ng} / \mathrm{mL})$ level were more likely [aOR $=1.45, p<0.05$ ] to be COVID-19 infected compared to the patients with $25(\mathrm{OH}) \mathrm{D}$ level $\geq 30 \mathrm{ng} / \mathrm{mL}$.

Baktash et al., 2020

Maghbooli et al., 2020
Vitamin D levels in the COVID-19-positive group were overall significantly lower compared with that in the COVID-19-negative group $(27.00 \mathrm{nmol} / \mathrm{L}$ vs. $52.00 \mathrm{nmol} / \mathrm{L})(p<0.05)$

- $\quad$ Severe disease infection was more prevalent in vitamin D deficiency patients compared to vitamin D sufficiency patients $(77.2 \%$ vs. $63.6 \%)$

- $\quad$ Patients who had a $25(\mathrm{OH}) \mathrm{D}<30 \mathrm{ng} / \mathrm{mL}$ that are vitamin D-deficient had more risk $[\mathrm{RR}=1.59, p$ $<0.05$ ] of having severe disease infection compared to the patients who had $25(\mathrm{OH}) \mathrm{D} \geq 30$ $\mathrm{ng} / \mathrm{mL}$ that are vitamin D-sufficient

Ye et al., 2020
- The serum 25(OH)D levels in COVID-19 patients $(55.6 \mathrm{nmol} / \mathrm{L})$ were statistically lower than in healthy controls $(71.8 \mathrm{nmol} / \mathrm{L})$

- Serum 25(OH)D levels in severe/critical COVID-19 cases (38.2 nmol/L) were significantly lower than that in mild/moderate cases $(56.6 \mathrm{nmol} / \mathrm{L})$

\section{Discussion}

The striking relationship between vitamin D deficiency and risk factors for COVID-19, such as obesity and older age, has influenced some scholars and researchers to postulate that vitamin D supplementations could be used as a preventive measure against COVID-19 disease [17]. Some researchers and clinicians have also argued that, since COVID-19 is associated with immune hyperactivation [11], vitamin D improves COVID-19 outcomes because it regulates immune pathological inflammatory responses and supports innate antiviral effector mechanism [17]. Zhong et al. [11] and Panarese and Shahini [12] independently report that vitamin $\mathrm{D}$ acts as a protective agent against COVID-19 because it boosts the immune system response to the SARS-CoV-2 virus.

Several studies [22-31] have investigated the likely protective or mitigating effect of vitamin D supplementations against COVID-19 infection and mortality. The present study contributes to the mounting existing evidence on the potential effect of vitamin D on COVID-19 status. Among the 11 studies which met the inclusion criteria for the 
current systematic review, all the studies suggested that vitamin D reduces the risk of COVID-19 infection, severity and mortality, with some caveats in the study by Hastie and colleagues. In other words, people who are vitamin D-sufficient are less likely to be infected and, even when infected, they are less likely to suffer critical illness or die from the COVID-19 infection.

The uniformity of evidence in the studies included in our systematic review suggests that there is a possibility that vitamin $\mathrm{D}$ supplementation might reduce the impact of COVID-19 especially in patients and populations with high prevalence of vitamin $\mathrm{D}$ deficiency [7-9]. Though the evidence from the review is positive and interesting, our discussion from the systematic review is driven from the relative lack of scientific knowledge relating to biological explanation for the vitamin D impacts on COVID-19 status, since only studies reporting likelihood were available and included. The studies reviewed and included in the evidence synthesis are based on cross-sectional, observational, and prospective data, and they do not provide indication of the relevant causative agents and mechanisms through which vitamin $\mathrm{D}$ serves as a protective or mitigating effect against COVID-19. This limitation does not suggest that the evidence of positive association between vitamin D and COVID-19 status must be dismissed.

However, without indicating the causative agents and plausible mechanism in the included studies, the level of confidence of the vitamin D impact on COVID-19 status is moderate. This is because if a COVID-19 patient is on vitamin D, a number of factors will determine whether a good effect is likely to occur. These factors include dose, duration, age, gender, diet, lifestyle state, and state of health, among others. These confounding factors may prove important in the vitamin D and COVID-19 status association. Evidently, one of the studies selected and included in this review [32] shows some uncertainties and also suggests that confounders should be taken into consideration when discussing effect of vitamin D on COVID-19 status. The authors found that vitamin D does not have a significant relationship with COVID-19 status in the presence of confounders. According to Martineau and Forouhi [17], results from studies investigating the potential and actual impact of vitamin D on COVID-19 status appear conflicting to date partly due to the evidence that those studies are open to residual and unmeasured confounding. The authors acknowledged, as a limitation, that some of the studies used for the present analysis used different reference values for vitamin D deficiency. Hence, there is lack of homogeneity in the doses of vitamin $\mathrm{D}$ that are considered deficient which may limit the accuracy of the conclusions drawn. We also acknowledge that the literature search was restricted between December 2019 and November 2020, hence there is an element of selection bias with current findings because of the non-inclusion of publications beyond this period. However, this type of selection bias is not unusual in published research materials from secondary data sources.

\section{Conclusions}

The findings from these studies suggest that vitamin D may serve as a mitigating effect for COVID-19 infection, severity, and mortality. The current evidence supports the recommendation for people at risk of COVID-19 infection to increase intake of foods rich in vitamin $\mathrm{D}$, such as fish, red meat, liver, and egg yolks. The evidence also supports the provision of vitamin D supplements to individuals with COVID-19 disease and those at risk of COVID-19 in order to boost their immunity and improve health outcomes. Notwithstanding, the amount of vitamin D-rich foods required to avoid deficiency is prohibitive for most people ( 25 eggs a day at minimum). Additional studies are required through rigorous research to include more recent publications and strengthen current evidence.

Supplementary Materials: Supplementary materials can be found at https://www.mdpi.com/ article/10.3390/covid1010008/s1.

Author Contributions: P.D. developed the study concept. P.D. and N.S. conducted the literature search, assessed the study quality and extracted the data. P.D., N.S., B.O.A., J.E.H.J., P.P., A.M. and 
A.-A.S. drafted the manuscript and revised the manuscript critically for important intellectual content. All authors have read and agreed to the published version of the manuscript.

Funding: The authors sincerely thank Bielefeld University, Germany for providing financial support through the Open Access Publication Fund for the article processing charge.

Institutional Review Board Statement: Not applicable.

Informed Consent Statement: Not applicable.

Data Availability Statement: The dataset is available upon request from the first author.

Acknowledgments: We thank Ebenezer Agbaglo of the Department of English, University of Cape Coast, Cape Coast, Ghana for thoroughly copyediting this manuscript.

Conflicts of Interest: The authors declare that they have no competing interests.

\author{
Abbreviations \\ AOR adjusted odds Ratio \\ HR Hazard ratio
}

\title{
References
}

1. World Health Organisation. WHO Coronavirus Disease (COVID-19) Dashboard. 2020. Available online: https://covid19.who.int/ (accessed on 11 November 2020).

2. Looi, M.K. Covid-19: Is a second wave hitting Europe? BMJ 2020, 371, m4113. [CrossRef]

3. Aleta, A.; Martin-Corral, D.; y Piontti, A.P.; Ajelli, M.; Litvinova, M.; Chinazzi, M.; Dean, N.E.; Halloran, M.E.; Longini, I.M., Jr.; Merler, S.; et al. Modeling the impact of social distancing, testing, contact tracing and household quarantine on second-wave scenarios of the COVID-19 epidemic. medRxiv 2020. [CrossRef]

4. Leung, K.; Wu, J.T.; Liu, D.; Leung, G.M. First-wave COVID-19 transmissibility and severity in China outside Hubei after control measures, and second-wave scenario planning: A modelling impact assessment. Lancet 2020, 395, 1382-1393. [CrossRef]

5. Laird, E.; Kenny, R.A. Vitamin D Deficiency in Ireland-Implications for COVID-19. Results from the Irish Longitudinal Study on Ageing (TILDA). 2020. Available online: https://tilda.tcd.ie/publications/reports/pdf/Report_Covid19VitaminD.pdf (accessed on 21 November 2020).

6. Richardson, D.P.; Lovegrove, J.A. Nutritional status of micronutrients as a possible and modifiable risk factor for COVID-19: A UK perspective. Br. J. Nutr. 2021, 125, 678-684. [CrossRef]

7. Ebadi, M.; Montano-Loza, A.J. Perspective: Improving vitamin D status in the management of COVID-19. Eur. J. Clin. Nutr. 2020, 74, 856-859. [CrossRef] [PubMed]

8. Grant, W.B.; Lahore, H.; McDonnell, S.L.; Baggerly, C.A.; French, C.B.; Aliano, J.L.; Bhattoa, H.P. Evidence that vitamin D supplementation could reduce risk of influenza and COVID-19 infections and deaths. Nutrients 2020, 12, 988. [CrossRef]

9. McCartney, D.M.; Byrne, D.G. Optimisation of vitamin D status for enhanced Immuno-protection against Covid-19. Ir. Med. J. 2020, 113, 58 .

10. Di Rosa, M.; Malaguarnera, M.; Nicoletti, F.; Malaguarnera, L. Vitamin D3: A helpful immuno-modulator. Immunology 2020, 134, 123-139. [CrossRef] [PubMed]

11. Zhong, J.; Tang, J.; Ye, C.; Dong, L. The immunology of COVID-19: Is immune modulation an option for treatment? Lancet Rheumatol. 2020, 2, e428-e436. [CrossRef]

12. Panarese, A.; Shahini, E. Covid-19, and vitamin D. Aliment. Pharmacol. Ther. 2020, 51, 993. [CrossRef]

13. Grasselli, G.; Tonetti, T.; Protti, A.; Langer, T.; Girardis, M.; Bellani, G.; Laffey, J.; Carrafiello, G.; Carsana, L.; Rizzuto, C.; et al. Pathophysiology of COVID-19-associated acute respiratory distress syndrome: A multicentre prospective observational study. Lancet Respir. Med. 2020, 8, 1201-1208. [CrossRef]

14. Ginde, A.A.; Mansbach, J.M.; Camargo, C.A. Association between serum 25-hydroxyvitamin D level and upper respiratory tract infection in the Third National Health and Nutrition Examination Survey. Arch. Intern. Med. 2009, 169, 384-390. [CrossRef]

15. Jolliffe, D.A.; Griffiths, C.J.; Martineau, A.R. Vitamin D in the prevention of acute respiratory infection: Systematic review of clinical studies. J. Steroid Biochem. Mol. Biol. 2020, 136, 321-329. [CrossRef] [PubMed]

16. Bergman, P.; Norlin, A.C.; Hansen, S.; Rekha, R.S.; Agerberth, B.; Björkhem-Bergman, L.; Ekström, L.; Lindh, J.D.; Andersson, J. Vitamin D3 supplementation in patients with frequent respiratory tract infections: A randomised and double-blind intervention study. BMJ Open 2012, 2, e001663. [CrossRef] [PubMed]

17. Martineau, A.R.; Forouhi, N.G. Vitamin D for COVID-19: A case to answer? Lancet Diabetes Endocrinol. 2020, 8, 735-736. [CrossRef]

18. Ali, N. Role of vitamin D in preventing of COVID-19 infection, progression and severity. J. Infect. Public Health 2020, 13, 1373-1380. [CrossRef]

19. Ilie, P.C.; Stefanescu, S.; Smith, L. The role of vitamin D in the prevention of coronavirus disease 2019 infection and mortality. Aging Clin. Exp. Res. 2020, 32, 1195-1198. [CrossRef] 
20. Walrand, S. Autumn COVID-19 surge dates in Europe correlated to latitudes, not to temperature-humidity, pointing to vitamin D as contributing factor. Sci. Rep. 2021, 11, 1981. [CrossRef] [PubMed]

21. Klingberg, E.; Oleröd, G.; Konar, J.; Petzold, M.; Hammarsten, O. Seasonal variations in serum 25-hydroxy vitamin D levels in a Swedish cohort. Endocrine 2015, 49, 800-808. [CrossRef] [PubMed]

22. Abrishami, A.; Dalili, N.; Torbati, P.M.; Asgari, R.; Arab-Ahmadi, M.; Behnam, B.; Sanei-Taheri, M. Possible association of vitamin D status with lung involvement and outcome in patients with COVID-19: A retrospective study. Eur. J. Nutr. 2020, 60, $2249-2257$. [CrossRef]

23. Radujkovic, A.; Hippchen, T.; Tiwari-Heckler, S.; Dreher, S.; Boxberger, M.; Merle, U. Vitamin D deficiency and outcome of COVID-19 patients. Nutrients 2020, 12, 2757. [CrossRef] [PubMed]

24. Maghbooli, Z.; Sahraian, M.A.; Ebrahimi, M.; Pazoki, M.; Kafan, S.; Tabriz, H.M.; Hadadi, A.; Montazeri, M.; Nasiri, M.; Shirvani, A.; et al. Vitamin D sufficiency, a serum 25-hydroxyvitamin D at least $30 \mathrm{ng} / \mathrm{mL}$ reduced risk for adverse clinical outcomes in patients with COVID-19 infection. PLoS ONE 2020, 15, e0239799. [CrossRef]

25. Macaya, F.; Espejo Paeres, C.; Valls, A.; Fernández-Ortiz, A.; Del Castillo, J.G.; Martín-Sánchez, F.J.; Runkle, I.; Rubio Herrera, M.Á. Interaction between age and vitamin D deficiency in severe COVID-19 infection. Nutr. Hosp. 2020, 37, 1039-1042. [CrossRef] [PubMed]

26. Ye, K.; Tang, F.; Liao, X.; Shaw, B.A.; Deng, M.; Huang, G.; Qin, Z.; Peng, X.; Xiao, H.; Chen, C.; et al. Does Serum Vitamin D Level Affect COVID-19 Infection and Its Severity?-A Case-Control Study. J. Am. Coll. Nutr. 2020, 1-8. [CrossRef]

27. Merzon, E.; Tworowski, D.; Gorohovski, A.; Vinker, S.; Golan Cohen, A.; Green, I.; Frenkel-Morgenstern, M. Low plasma 25(OH) vitamin D level is associated with increased risk of COVID-19 infection: An Israeli population-based study. FEBS J. 2020, 287, 3693-3702. [CrossRef]

28. Meltzer, D.O.; Best, T.J.; Zhang, H.; Vokes, T.; Arora, V.; Solway, J. Association of Vitamin D Status and Other Clinical Characteristics With COVID-19 Test Results. JAMA Netw. Open 2020, 3, e2019722. [CrossRef] [PubMed]

29. Kaufman, H.W.; Niles, J.K.; Kroll, M.H.; Bi, C.; Holick, M.F. SARS-CoV-2 positivity rates associated with circulating 25hydroxyvitamin D levels. PLoS ONE 2020, 15, e0239252. [CrossRef]

30. D'avolio, A.; Avataneo, V.; Manca, A.; Cusato, J.; De Nicolò, A.; Lucchini, R.; Keller, F.; Cantù, M. 25-hydroxyvitamin D concentrations are lower in patients with positive PCR for SARS-CoV-2. Nutrients 2020, 12, 1359. [CrossRef]

31. Baktash, V.; Hosack, T.; Patel, N.; Shah, S.; Kandiah, P.; Van den Abbeele, K.; Mandal, A.K.J.; Missouris, C.G. Vitamin D status and outcomes for hospitalised older patients with COVID-19. Postgrad. Med. J. 2020, 2, 1-6. [CrossRef]

32. Hastie, C.E.; Mackay, D.F.; Ho, F.; Celis-Morales, C.A.; Katikireddi, S.V.; Niedzwiedz, C.L.; Jani, B.D.; Welsh, P.; Mair, F.S.; Gray, S.R.; et al. Vitamin D concentrations and COVID-19 infection in UK Biobank. Diabetes Metab. Syndr. Clin. Res. Rev. 2020, 14, 561-565. [CrossRef] 